\title{
APPARATUS FOR TEACHING SCIENCE IN SCHOOLS
}

$I^{\mathrm{N}}$ the second part of his articles on "Science Education Today"*, J. L. Lewis of Malvern College examines what has been done by the Esso Loan Service of Scientific Apparatus to Preparatory Schools. This has been applied only in the limited field of preparatory schools in Britain, but the influence it has had suggests that the methods could be applied more widely with remarkable effect.

In the past only a small number of preparatory schools taught any science: boys from most schools went on to their public schools at the age of 13 and began science there. For various reasons it was felt that science should be introduced into preparatory schools. The problems appeared insuperable: there were no laboratories, no apparatus, no scientists to teach. The Esso Scheme was tried as an experiment in about thirty schools. An existing series of science books was chosen; the schools were supplied with quantities of these, together with units of apparatus to enable every experiment described in the text to be performed by the teacher. In addition, it was assumed that many of the schools would not get the services of a qualified scientist to teach science, so that experienced teachers were invited to write a teacher's guide, specially to help the non-scientist in the presentation of the subject.

Such was the initial enthusiasm that it was soon developed and supplied, without any cost at all, to more than 150 schools. It has since been offered to

* Esso Magazine. Spring 1962 (see also Nature, 194, 1+1; 1982). every Associated Preparatory School in Britain. The result has been remarkable. From September next, more than 400 schools, which formerly were teaching no science at all, will be teaching it. Units on Weather and the Earth, Heuring and Seeing, Energy and Engines, Electric Currents, Freshwater Life, Earth and Universe, Heating and Cooling, Air and Water will be going to all parts of Britain to remain in a school for a term, enabling a course to be run until another unit arrives to take its place.

Another service has been rendered by Esso's Senior Loan Service of Scientific Apparatus to Schools. This, too, has grown from small beginnings to something much valued in the educational world. Under this, the Company has made available certain items of apparatus, usually of the more expensive type, which is often beyond the means of many schools, such as $p \mathrm{H}$ meters, double-beam oscilloscopes, ratemeters, signal generators, optical pyrometers and viscometers. These are loaned to a school free of charge for one term. The scheme has enabled pupil and teacher alike to become familiar with lessusual apparatus; it has enabled more sophisticated experiments to be carried out, and even small research projects.

A most important development of the Loan Service is now planned, a development likely to be of the greatest value, as its influence will ultimately be of benefit to all schools. Another helpful service is the proposed film on the teaching of modern physics which the Esso Film Unit is planning.

\section{HEART DISEASE IN THE BANTU}

$\mathrm{T}$ THE annual report of the South African Institute for Medical Research* is noteworthy, besides a number of other interesting features, for a series of investigations bearing on coronary heart disease in the Bantu.

Studies by Dr. F. W. Fox on two rural Bantu groups, namely, Pedi Bantu (Sekhukhuniland region) and Tswana Bantu (south-west Bechuanaland) indicate that, in view of the extremely low incidence of myocardial infarction found among both rural and urban Bantu, it would seem that intensive nutritional and other investigations should be concentrated on that fraction of urban Bantu living closest in diet and manner of life to South African Whites; and that fraction of very poor Whites whose environment factors conform in measure to those of the Bantu.

The present belief that diets very high in animal fat are necessarily promotive of atherosclerosis and mortality from ischimic heart disease may not be valid irrespective of the dietary setting, and it is suggested that investigations of indigenous nomadic groups in north-east Africa, who subsist largely on milk from eamels, goats and sheep, may be rewarding from the point of view not only of their very high intake of animal fat but also of animal protein and calcium.

* The South African Institute for Medical Research. Annual Report for the year 1960. Pp. 191. (Johannesburg: The South Africun Institute for Medical Research, 1061.)
Electrocardiograph studies have been carried out on groups of rural Pedi and Baralong Bantu; among 1,100 subjects only four gave evidence of infaretion, all of whom were more than 75 years of age. Of Urban Bantu, among 385 Johannesburg pensioners (virtually all more than 60 years), one positive was found, aged 63 years. Apart from the foregoing study, there is little doubt that the results of electrocardiograph observations on Bantu populations at risk are in complete harmony with the conclusion reached from several large series of necropsies on Bantu undertaken at different centres in the Union, that is, the occurrence of, and mortality from, acute episodes of coronary heart disease among these people is virtually nil. The critical population next to be considered is the most sophisticated group of Bantu available. If the latter conforms to the reaction of Yominite immigrants in Israel, and Japanese immigrants in California, then an increasing incidence of myocardial infarction would be expected.

Reports from Durban suggest that local Indians are as prone as local Whites to die from coronary heart disease and, incidentally, diabetes. Mortality from this disease, however, appears to be much lower among Indians in India. The situation regarding Durban Indians is unexpected; electrocardiograph, blood pressure, dietary and other investigations are 
being carried out by Indian research assistants on Indian population groups in Johannesburg and Pretoria.

Death certificates suggest that South African Whites are probably as prone as overseas White populations to die from coronary heart disease. To give perspective to the electrocardiograph investigations on the Bantu, and to learn something of the incidence of myocardial ischæmia in representative local White populations with the co-operation of the authorities, electrocardiograph and other investigations have been carried out on 248 White persons. Assessment of tracings is still in progress. Permission from the relevant authorities has been obtained to carry out an investigation of 'total heart disease' in a group of workers-a study which will require intensive short-term co-operation from several physicians and other workers.

Other investigations have also shown the commonness of hypertension in the Bantu, a feature associated with a high incidence and mortality from cerebral vascular disease, but with virtually no mortality from coronary heart disease. In endeavours to throw light on hypertension in these people, a number of investigations have been carried out. Blood pressure and other investigations have been undertaken at schools previously visited for nutritional and biochemical studies in the Rustenburg, Hartebeestpoort and Witkoppen regions. It is apparent that blood pressure at one particular school is significantly lower than that of the others. Investigations on blood pressure have also been carried out on groups of mineworkers from different regions. Some differ. ences are apparent; for example, hypertension occurs less among Xhosa compared with Shangaan and Tswana Bantu.

Some Bantu groups are habituated to very soft water; others add plant ashes of variable composition to their food. There is one Bantu group, however, habituated to an unusually high intake of salt, the sole source of water (wells) having a salinity of about a quarter that of sea-water. This group, at Kukong, Southern Kalahari Desert, is being studied from the point of view of blood pressure, electrocardiograph, blood biochemistry and other aspects. Observations will be compared with those on another group dwelling nearby, but habituated to soft drinkingwater. This possibly unique natural situation should shed light on the influence of an unusually high intake of salt on hypertension in the Bantu.

\section{EURYHALINE EUGLENOID FLAGELLATES}

\begin{abstract}
A RECENTLY published pamphlet* is Part 8 of a series which, when completed, will be the first attempt to give a comprehensive account of the unicellular, mostly motile, algae occurring in British coastal and estuarine waters. It is the second part to appear, Part 1, containing the general introduction to the series, definitions, bibliography and the taxonomic section on Chlorophyceae having been published in 1959. Part, 8 consists of the taxonomic section on euryhaline Euglenineae. Since the series will deal with organisms of great importance for fishery and sea-food investigations, and since a taxonomic account of these organisms is not otherwise available, it is to be regretted that the pamphlet under review contains so many inaccuracies that its use cannot be recommended.

In the short description of the class Euglenineae with which the pamphlet begins there are omissions, misconceptions and several factual errors. For example, "Flagellum one or two" is incorrect for the Euglenineae, modern cytological studies having established the taxonomically important fact that all euglenoid flagellates have two flagella. Apart from the genera with two externally emergent flagella (for example, Distigma, Eutreptia, Peranema), most genera (for example, Astasia, Colacium, Euglena, Lepocinclis, Phacus, Trachelomonas) have one long flagellum which is emergent from the canal and functional in swimming. and a second flagellum which ends within the reservoir. This short flagellum is an independent organelle though its tip may be apposed to the longer flagellum, an arrangement which led to the old, erroneous description of a single flagellum bifurcate at the base. Other points needing correction are that emergent flagella with unilateral masti-

* Ministry of Agriculture, Fisheries and Food. Fishery Investiga tions, Series IV: An Introductory Account of the Smaller Algae of British Coastal Waters. Part VIII: Euglenophyceae $=$ Euglenineae. By Dr. R. W. Butcher. Pp. v+17+3 plates. (London: H.M. Stationery Office, 1961.) $12 s .6 d$. net.
\end{abstract}

gonemes have been demonstrated for more genera than those quoted, notably Phacus and Trachelomonas; colonial euglenoids are known, for example, Colacium mucronatum, which forms extensive dendroid colonies; members of the Euglenaceae and Astasiaceae are described as having "simple bilateral sym. metry" whereas one of the major taxonomic features of the euglenoid cell is its helical asymmetry; organisms in the Peranemaceae are said to have "complex dorsiventral organization" without the rider that such organization is found in species of most genera and is superimposed on the underlying helical asymmetry; the statement that "Euglena gracilis becomes colourless if grown in the dark" is misleading in its context, since permanent apochlorosis equivalent to the condition in Astasis is produced only if treatment with high temperature, ultra-violet irradiation, antihistamines or streptomycin is also applied; finally, Distigma cannot be said to be "the colourless counterpart of Eutreptia" in the way that species of Astasia might be for species of Euglena, or Hyalophacus is for Phacus.

Mistakes in the opening section are repeated in the key to the genera of the Euglenaceae (the only family dealt with in the pamphlet) and in the descriptions of genera and species. For example, the erroneous concept of species with only one flagellum appears several times and is carried to greater lengths for Euglena obtusa and $E$. vermiformis. $E$. obtusa is described as having "complete absence of a flagellum" when in fact it has two perfectly good flagella. It is true that in this species both flagella terminate within the reservoir at about the level of the eyespot. Dr. Butcher mentions a flagellar "vestige inside the canal" without apparently realizing its significance. As a practical point of distinction in the specific key it would be correct to say for $E$. obtusa "neither flagellum emergent" or, possibly, "no locomotory flagellum". 